\title{
Management of dyspnea at the end of life
}

\author{
Michael P. Slawnych MD PhD
}

Cite as: CMAJ 2020 May 19;192:E550. doi: 10.1503/cmaj.200488; early-released April 21, 2020

CMAJ Podcasts: author interview at https://soundcloud.com/cmajpodcasts/200488-five

\section{1} No one should die suffering from breathlessness

All physicians should be prepared to manage dyspnea, especially during the coronavirus disease 2019 pandemic. ${ }^{1}$ Dyspnea, a subjective experience of uncomfortable breathlessness, can usually be well managed using subcutaneous medications, with a butterfly infusion set being a good access option because it prevents the need for repeated needle injections and can remain in place for days. ${ }^{2}$

2 Opioids are the mainstay for managing dyspnea at the end of life It is suggested that physicians start with opioids, ${ }^{3}$ which do not impair respiratory status or hasten death when used appropriately with a symptom focus (e.g., hydromorphone $0.5 \mathrm{mg}$ subcutaneously every $4 \mathrm{~h}$, and $0.5 \mathrm{mg}$ subcutaneously every $30 \mathrm{~min}$, as needed). ${ }^{4}$ The dosage should be reassessed frequently. Physicians should be prepared to escalate the dose rapidly if necessary. Subcutaneous opioids are twice as powerful as oral opioids (e.g., hydromorphone $1.0 \mathrm{mg}$ taken orally has about the same effect as $0.5 \mathrm{mg}$ administered subcutaneously).

\section{If dyspnea persists, a benzodiazepine may be added}

Benzodiazepines can be helpful, particularly if the patient has associated anxiety (e.g., lorazepam $0.5 \mathrm{mg}$ subcutaneously every $2 \mathrm{~h}$, as needed [the dose can be increased if necessary]). For ongoing refractory dyspnea, palliative sedation may be required. A palliative physician should be involved if progressing to this treatment.

Patients often develop bothersome secretions owing to swallowing difficulties

There is usually no role for suctioning, which is often uncomfortable for patients. Anticholinergics are the medication of choice to reduce secretions. Clinicians may choose between scopolamine and glycopyrrolate depending on whether sedation is preferred (e.g., scopolamine $0.4 \mathrm{mg}$ subcutaneously every $4 \mathrm{~h}$ as needed [sedating]; glycopyrrolate $0.4 \mathrm{mg}$ subcutaneously every $4 \mathrm{~h}$ as needed [not sedating]). Mouth swabs can be helpful for mouth dryness.

5 Patients' dyspnea-related agitation can distress their loved ones Using an antipsychotic is suggested for managing agitation. Methotrimeprazine is favoured because of its sedative properties (e.g., methotrimeprazine $6.25 \mathrm{mg}$ subcutaneously every $6 \mathrm{~h}$ as needed [the dose can be increased if needed]). A benzodiazepine is also sometimes added, particularly near the end of life.

\section{References}

1. Arya A, Buchman S, Gagnon B, et al. Pandemic palliative care: beyond ventilators and saving lives. CMAJ 2020;192: E400-4.

2. Goldstein NE, Morrison RS. Evidence-based practice of palliative medicine. Philadelphia: Elsevier Saunders; 2013.

3. Currow DC, Ward AM, Abernethy AP. Advances in the pharmacological management of breathlessness. Curr Opin Support Palliat Care 2009;3:103-6.

4. Gallagher R. Killing the symptom without killing the patient. Can Fam Physician 2010;56:544-6, e210-2.

Competing interests: Michael Slawnych reports receiving a speaker fee as a member of a speaker bureau, Novartis.

This article has been peer reviewed.

Affiliations: Division of Palliative Care and Libin Cardiovascular Institute, University of Calgary, Calgary, Alta.

Correspondence to: Michael Slawnych, michael.slawnych@ahs.ca

CMAJ invites submissions to "Five things to know about ..." Submit manuscripts online at http://mc. manuscriptcentral.com/cmaj 